Saudi Journal of Medicine

Abbreviated Key Title: Saudi J Med ISSN 2518-3389 (Print) |ISSN 2518-3397 (Online) Scholars Middle East Publishers, Dubai, United Arab Emirates Journal homepage: https://saudijournals.com/sjm

Original Research Article

\title{
A Study of Drug Used in the Treatment of Acne Vulgaris
}

\author{
Dr. Laxminarayana Bhat ${ }^{*}$
}

Associate Professor, Department of Dermatology, Kanachur Institute of Medical Sciences, Mangalore-Thokkottu-Konaje University Rd, Kotekar Village, Deralakatte, Karnataka 575018, India

DOI: $10.36348 /$ sjm.2020.v05i04.002 $\quad$ | Received: 31.03 .2020 | Accepted: 07.04 .2020 | Published: 13.04 .2020

*Corresponding author: Dr. Laxminarayana Bhat

\section{Abstract}

Acne is known to be a disease of the adolescents affecting approximately $85 \%-90 \%$ of the teenagers. It is most commonly present between the ages of 10 and 13 years in both sexes with the mean age of onset of acne being 11 years in girls and 12 years in boys. Acne is now presenting earlier and lasting longer. This study puts in an effort to find the most commonly used drugs in the treatment of acne vulgaris.

Keywords: Acne, Vulgaris, Drugs, Treatment.

Copyright @ 2020: This is an open-access article distributed under the terms of the Creative Commons Attribution license which permits unrestricted use, distribution, and reproduction in any medium for non-commercial use (NonCommercial, or CC-BY-NC) provided the original author and source are credited.

\section{INTRODUCTION}

Early and aggressive treatment is advocated by some to lessen the overall long-term impact to individuals [1]. Acne is a treatable disease, but the treatment usually lasts for many years and it may influence many aspects of patient's life. In majority of the cases, the patient's adherence to treatment is directly dependent on cost of treatment and compliance with treatment regimen is an essential element in overall effectiveness of therapy. In the Indian market, drugs of various brands are available for the treatment of acne vulgaris. This creates a lot of confusion for the physician to decide the brand of choice for their patients. Literature search revealed very few studies which compared the cost of drugs of different brands for acne vulgaris [2-5]. Acne is known to be a disease of the adolescents affecting approximately $85 \%-90 \%$ of the teenagers [6, 7]. It is most commonly present between the ages of 10 and 13 years in both sexes with the mean age of onset of acne being 11 years in girls and 12 years in boys [8,9]. Acne is now presenting earlier and lasting longer [10].

This study puts in an effort to find the most commonly used drugs in the treatment of acne vulgaris.

Aims and Objectives: To study the commonly used drugs in the treatment of acne vulgaris.

\section{MATERIALS AND METHODS}

- This study was done in the Department of Dermatology, Kanachur Institute of Medical Sciences, Deralakatte, Mangalore.

- This study was done from September 2019 to December 2019.

- The treatment which was prescribed for Acne Vulgaris was taken and then was reported.

- 120 patients were checked and analysed.

\section{RESULTS}

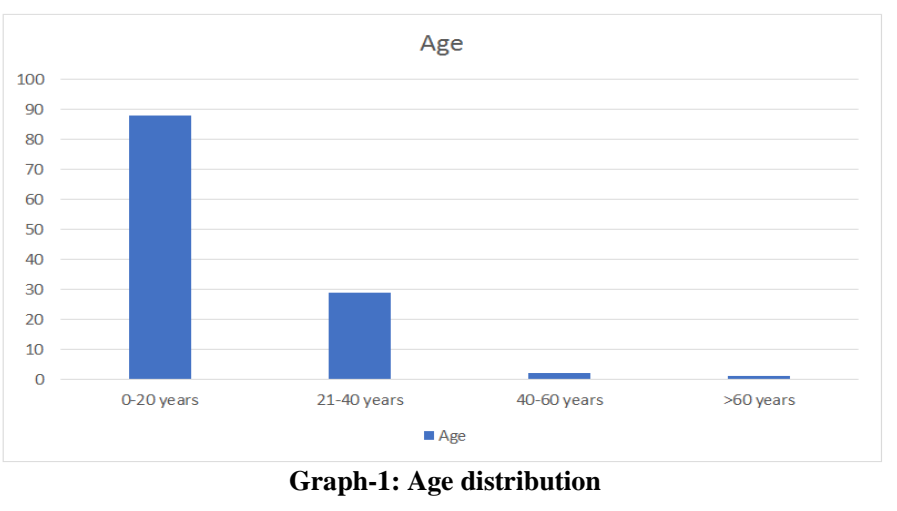




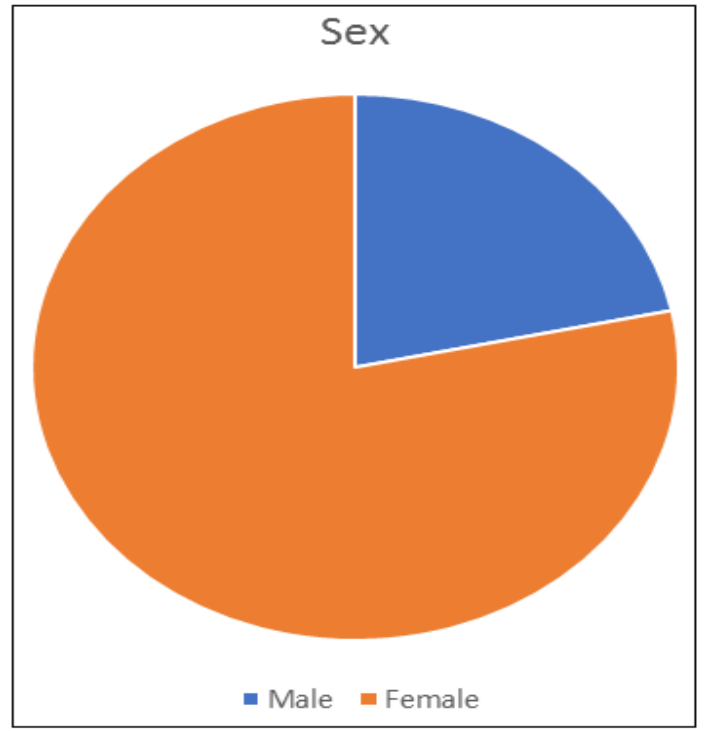

Graph-2: Sex Distribution

Table-1: Drugs prescribed

\begin{tabular}{|l|l|}
\hline Retinoid & 71 \\
\hline Vitamins & 86 \\
\hline Antifungal & 03 \\
\hline Antimicrobials & 56 \\
\hline Corticosteroids & 41 \\
\hline $\begin{array}{l}\text { Amoxicillin+Clavulanicacid } \\
\text { Diclofenac+Serratiopeptidase }\end{array}$ & 7 \\
\hline Antihistaminics & 91 \\
\hline Anti-inflammatory & 74 \\
\hline
\end{tabular}

\section{DISCUSSION}

We found that retinoids (Tretinoin, Adapalene, and Isotretinoin) were prescribed both topically as well as orally in patients. Topical tretinoin and adapalene are recommended as monotherapy in primarily comedonal acne, or in combination with topical or oral antimicrobials in patients with mixed or primarily inflammatory acne lesions. These can also be safely used in the management of preadolescent acne in children. Oral isotretinoin was recommended in our study patients for the treatment of some cases of Grade II and all cases of Grade IV acne. Isotretinoin is appropriate for the treatment of moderate acne that is treatment-resistant or for the management of acne that is producing physical scarring or psychosocial distress $[11,12]$. Low-dose isotretinoin can be used to effectively treat acne and reduce the frequency and severity of medication-related side effects [13, 14]. Topical antimicrobials (e.g., erythromycin and clindamycin) are effective acne treatments, but are not recommended to be prescribed alone because of the risk of development of bacterial resistance. They should always be given along with another topical or systemic antimicrobial; retinoids (oral or topical); benzoyl peroxide, etc [14]. Similar prescription trend was seen in the study which speaks about the rationality of prescriptions for acne vulgaris in this set up. Regarding systemic antimicrobials use, American Academy of Dermatologists have proposed that systemic antimicrobials should be recommended in the management of moderate to severe acne and forms of inflammatory acne that are resistant to topical treatments. They also proposed doxycycline and minocycline are more effective than tetracycline, but neither is superior to each other whereas oral erythromycin and azithromycin can be effective in treating acne but its use should be limited to those who cannot use tetracycline.[14] In mild and noninflammatory acne they prescribed Azithromycin over tetracycline as it is known to be safe and effective with better patient compliance [15-17].

\section{CONCLUSION}

The drugs that was usually prescribed is successfully reported so as to be useful to the Practising physicians and Dermatologists.

\section{REFERENCES}

1. Goodman, G. (2006). Acne and acne scarring: the case for active and early intervention. Australian family physician, 35(7), 503-504.

2. Bossuyt, L., Bosschaert, J., Richert, B., Cromphaut, P., MITCHELL, T., Al Abadie, M., ... \& Czernielewski, J. (2003). Lymecycline in the treatment of acne: an efficacious, safe and costeffective alternative to minocycline. European Journal of Dermatology, 13(2), 130-5.

3. Narwane, S. P., Patel, T. C., Shetty, Y. C., \& Chikhalkar, S. B. (2011). Drug utilization and cost analysis for common skin diseases in dermatology OPD of an Indian tertiary care hospital-A prescription survey. Journal of Pharmaceutical Research International, 9-18.

4. Balkrishnan, R., Kulkarni, A. S., Cayce, K., \& Feldman, S. R. (2006). Predictors of healthcare outcomes and costs related to medication use in patients with acne in the United States. Cutis, 77(4), 251-255.

5. Shankar, P. R., Subish, P., Bhandari, R. B., Mishra, P., \& Saha, A. C. (2017). Ambiguous pricing of topical dermatological products: A survey of brands from two South Asian countries. Journal of Pakistan Association of Dermatology, 16(3), 134-140.

6. Stathakis, V., Kilkenny, M., \& Marks, R. (1997). Descriptive epidemiology of acne vulgaris in the community. Australasian journal of dermatology, 38(3), 115-123.

7. Kraning, K. K., \& Odland, G. F. (1979). Supplemental issue-analysis of research needs and priorities in dermatology. Journal of Investigative Dermatology, 73(5), 395-513.

8. Dreno, B., \& Poli, F. (2003). Epidemiology of acne. Dermatology, 206(1), 7-10.

9. Schäfer, T., Nienhaus, A., Vieluf, D., Berger, J., \& Ring, J. (2001). Epidemiology of acne in the 
general population: the risk of smoking. British journal of dermatology, 145(1), 100-104.

10. Griffiths, C., Barker, J., Bleiker, T., Chalmers, R., \& Creamer, D. (Eds.). (2016). Rook's textbook of dermatology. John Wiley \& Sons.

11. Khunger, N., \& Kumar, C. (2012). A clinicoepidemiological study of adult acne: is it different from adolescent acne?. Indian Journal of Dermatology, Venereology, and Leprology, 78(3), 335.

12. Swati, G., \& Kusagur, M. S. (2015). A clinicoepidemiological study of acne in adults. IJSR, 4, 822-825.

13. Patro, N., Jena, M., Panda, M., \& Dash, M. (2015). A study on the prescribing pattern of drugs for acne in a tertiary care teaching hospital in odisha. Journal of clinical and diagnostic research: JCDR, 9(3), WC04.
14. Zaenglein, A. L., Pathy, A. L., Schlosser, B. J., Alikhan, A., Baldwin, H. E., Berson, D. S., ... \& Keri, J. E. (2016). Guidelines of care for the management of acne vulgaris. Journal of the American Academy of Dermatology, 74(5), 945973.

15. Fernandez- Obregon, A. C. (2000). Azithromycin for the treatment of acne. International journal of dermatology, 39(1), 45-50.

16. Bardazzi, F., Savoia, F., Parente, G., Tabanelli, M., Balestri, R., Spadola, G., \& Dika, E. (2007). Azithromycin: a new therapeutical strategy for acne in adolescents. Dermatology online journal, 13(4), 4-14.

17. Kapadia, N., \& Talib, A. (2004). Acne treated successfully with azithromycin. International journal of dermatology, 43(10), 766-767. 